\title{
Study on Partial Replacement of Cement with Waste Paper Sludge Ash in Fibre Reinforced Concrete
}

\author{
Mounika Ch. ${ }^{1}$, Asif Ali Sk. ${ }^{2}$ \\ ${ }^{1}$ PG Student of Structural Engineering, Amrita Sai Institute of Science and Technology, Paritala, Andhra Pradesh, India. \\ ${ }^{2}$ Assistant Professor, Department of Civil Engineering, Amrita Sai Institute of Science and Technology, Paritala, Andhra Pradesh, India
}

\begin{abstract}
Portland cement is the most important ingredient of concrete and is a versatile and relatively high cost material. Large scale production of cement is causing environmental problems on one hand and depletion of natural resources on other hand. This work examines the possibility of using waste paper sludge ash to produce a low cost concrete by blending various ratios of cement with paper sludge ash and to reduce disposal and pollution problems due to waste paper sludge ash. The innovative use of waste paper sludge ash in concrete as a supplementary cementitious material was tested as an alternative to fibre reinforced concrete. In this study waste paper sludge ash was partially replaced from $5 \%, 10 \%, 15 \%$ in cement to get optimum point and from this optimum point addition of glass fibres with different proportions i.e from $0.1 \%, 0.2 \%, 0.3 \%, 0.4 \%$ and also steel fibres with different proportions i.e from $0.5 \%$, $1 \%$, $1.5 \%, 2 \%$ are used in concrete for M25 mix and tested for its compressive strength, splitting tensile strength and flexural strength up to 28 days of strength and compared with conventional concrete. Durability tests are also conducted for these mixes with $5 \%$ of $\mathrm{H} 2 \mathrm{So} 4$ and $\mathrm{HCl}$. Test results indicate that use of waste paper sludge ash in concrete has improved the performance of concrete in strength aspect
\end{abstract}

Keywords: Compressive strength, Durability, split tensile strength, Flexural strength, Durability, Waste Paper Sludge Ash, M25Concrete

\section{Introduction}

In order to make concrete industry sustainable, the use of waste materials in place of natural resources is one of the best approaches. Paper mill sludge is a major economic and environmental problem for the paper and board industry. An enormous quantity of waste paper sludge is generated all around the world. In India, $0.7 \%$ of total urban waste generated comprises of paper sludge. Paper mill sludge is a major economic and environmental problem for the paper and board industry. The material is a by-product of the deinking and re-pulping of paper. In functional terms, paper sludge consists of cellulose fibers, fillers such as calcium carbonate and china clay and residual chemicals bound up with water. The moisture content is typically up to $40 \%$. The material is viscous, sticky and hard to dry and can vary in viscosity and lumpiness. It has an energy content that makes it a useful candidate as an alternative fuel for the manufacture of Portland cement. This research will summarize the behaviour of concrete with the waste paper sludge ash by replacement of cement in the range of 5\%,10\% and $15 \%$ which may help to reduce the disposal problem of sludge and enhance the properties of M25 concrete. As wastepaper sludge ash contains higher percentage of silicon dioxide $\mathrm{SiO} 2$, it may provide extra strength to concrete. In addition to these fibres are also added to obtain more strength.

\section{Materials and Properties}

In this research work various materials like Cement, Fine Aggregate ,Coarse Aggregate, water, glass and steel fibers were used and their properties are examined by taking the help of IS [INDIAN STANDARD] codes.

\subsection{Cement}

Ordinary Portland cement of 53 Grade was preferred for this study. The physical properties of cement are categorized as per IS 456-2000

Table 1: Properties of cement

\begin{tabular}{|c|c|c|c|}
\hline S.No & Properties & Value & $\begin{array}{c}\text { Permissible limit as per } \\
\text { IS: } 12269-1987\end{array}$ \\
\hline 1 & Specific Gravity & 3.12 & Varies from 3.1 to 3.15 \\
\hline 2 & Initial Setting time & $58 \mathrm{~min}$ & $\begin{array}{c}\text { Should not be less than } \\
30 \text { Min }\end{array}$ \\
\hline 3 & Final Setting time & 300 min & $\begin{array}{c}\text { Should not be more than } \\
600 \text { Min }\end{array}$ \\
\hline 4 & Fineness test & $1 \%$ retained & $<10 \%$ \\
\hline
\end{tabular}

\subsection{Fine Aggregates}

Locally available river sand was preferred as fine aggregate for entire experimental work. The physical properties of sand was carried out by taking the help of IS 383-1970 and IS 2386-1963 code books.

Table 2: Properties of fine aggregate

\begin{tabular}{|c|c|c|c|}
\hline S.No & Properties & Value & $\begin{array}{c}\text { Permissible limit as per } \\
\text { IS: 383-1970 }\end{array}$ \\
\hline 1 & Specific Gravity & 2.6 & $\begin{array}{c}\text { Should be between the } \\
\text { limit 2.6-2.7 }\end{array}$ \\
\hline 2 & Fineness Modulus & 2.73 & $2-4$ \\
\hline 3 & Grading Zone & Zone II & -- \\
\hline
\end{tabular}

\subsection{Coarse Aggregate}

Crushed Granite stone of sizes $20 \mathrm{~mm}$ and $10 \mathrm{~mm}$ were selected for this work. Taking the reference of IS codes the properties of coarse aggregate have been tested 


\section{International Journal of Science and Research (IJSR) \\ ISSN (Online): 2319-7064}

Index Copernicus Value (2015): 78.96 | Impact Factor (2015): 6.391

Table 3: Properties of coarse aggregate

\begin{tabular}{|c|c|c|c|}
\hline S.No & Properties & Value & $\begin{array}{c}\text { Permissible limit as per IS: } \\
2386-1963\end{array}$ \\
\hline 1 & Specific Gravity & 2.64 & In between range 2.6-2.8 \\
\hline 2 & Fineness Modulus & 6.48 & $6.5-8$ \\
\hline
\end{tabular}

\subsection{Waste Paper sludge ash}

This material is collected from Vedadri Paper Mills(India) pvt. Ltd. The chemical properties of waste paper sludge ash are

Table 4: Chemical Composition of Waste Paper Sludge Ash

\begin{tabular}{|c|c|}
\hline Property & Value \\
\hline Silicon Dioxide & $59.47 \%$ \\
\hline Calcium Oxide & $8.69 \%$ \\
\hline Alumina and Ferric Oxide & $10.45 \%$ \\
\hline Magnesium Oxide & $3.13 \%$ \\
\hline
\end{tabular}

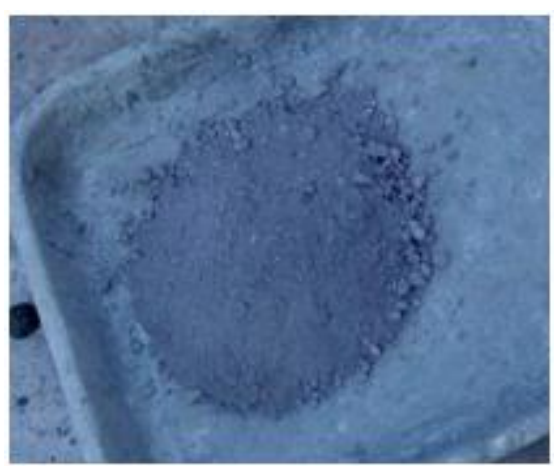

Figure 1: Waste paper sludge ash

\subsection{Fibres}

\subsubsection{Steel fibres}

- Diameter:- $0.5 \mathrm{~mm}$

- Length:- Available in30mm

- Density:- density of steel fibre is $7900 \mathrm{~kg} / \mathrm{m} 3$

- Aspect Ratio:- 60

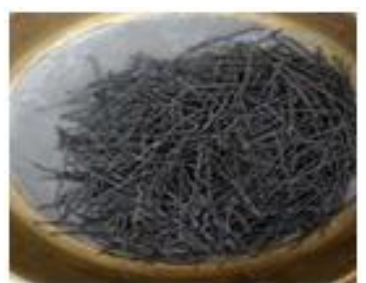

Figure 2: Hooked steel fibres

\subsubsection{Glass fibres}

The type glass fibres use are ar- glass type fibres.the properties are given below. The length of glass fibres is $50 \mathrm{~mm}$ and diameter is $0.1 \mathrm{~mm}$.

Table 5: Properties of Glass Fibres

\begin{tabular}{|c|c|}
\hline Property & Value \\
\hline Density, $\left(\mathrm{g} / \mathrm{Cm}^{3}\right)$ & 2.7 \\
\hline Tensile Strength, MPa & 1700 \\
\hline Modulus, GPa & 72 \\
\hline Percent Elongation & 2.3 \\
\hline
\end{tabular}

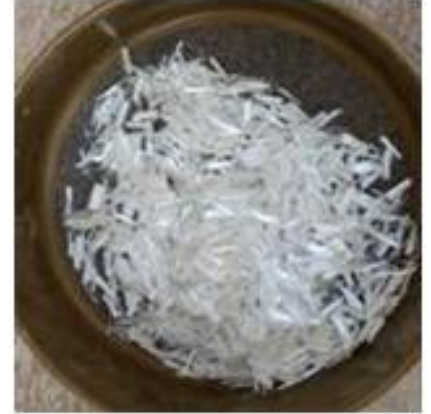

Figure 3: Glass fibres

\section{Concrete Mix Proportion}

The mix design for M25 has carried out by following the specifications and limitations of Indian Standard Code (IS 10262-2009). The target meant strength was inspected as $34.5 \mathrm{~N} / \mathrm{mm} 2$. The water to cement ratio is taken as 0.45 . The mix proportion for M25 grade concrete is 1:1.34:2.76

Table 6: Results of M25 Mix

\begin{tabular}{|c|c|c|c|}
\hline Material & Cement & Fine aggregate & Coarse aggregate \\
\hline $\mathrm{Kg} / \mathrm{m}^{3}$ & 406.33 & 659.23 & 1116.05 \\
\hline
\end{tabular}

\section{Tests Done on Concrete for Strength and Durability}

A number of tests were conducted on concrete determine the design mix properties of concrete in the laboratory. The strength criterion includes measurement of following parameters:

\subsection{Compressive Test}

Compressive strength is obtained by applying crushing load on the cube surface. So it is also called as Crushing strength. Compressive strength of concrete is calculated by casting $150 \mathrm{~mm} \times 150 \mathrm{~mm} \times 150 \mathrm{~mm}$ cubes. The test results are presented here for the Compressive strength of 7 days, 28 days testing.
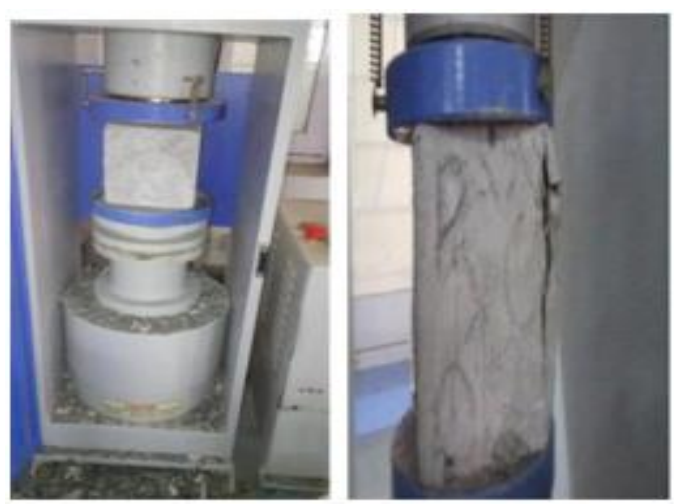

Figure 4: Testing of cubes in compressive testing machine

\subsection{Split tensile Test}

Split tensile was performed on cylinders $150 \mathrm{~mm}$ dia. and $300 \mathrm{~mm}$ height on compression testing machine. The failure load was recorded to find out split tensile strength. After testing the concrete (split tensile strength) for M25 grade

\section{Volume 6 Issue 7, July 2017 www.ijsr.net}




\section{International Journal of Science and Research (IJSR) \\ ISSN (Online): 2319-7064 \\ Index Copernicus Value (2015): 78.96 | Impact Factor (2015): 6.391}

concrete separately for replacement of sludge ash and adding glass \& steel fibre by cement respectively finally combined percentage of sludge ash and adding glass \& steel fibre in which maximum strength is obtained was used to get optimized strength.

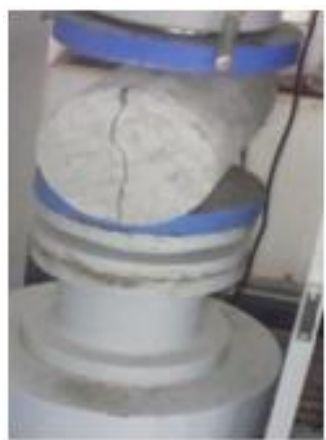

Figure 5: Testing of cylinders in split tensile testing machine

\subsection{Flexural Test}

Flexural test was performed on beams by placing them on universal find out the flexural strength. After testing the concrete (flexural strength) for M25 grade concrete separately for replacement of sludge ash and adding glass \& steel fibre by cement respectively finally combined percentage of sludge ash and adding glass \& steel fibre in which maximum strength is obtained was used to get optimized strength.
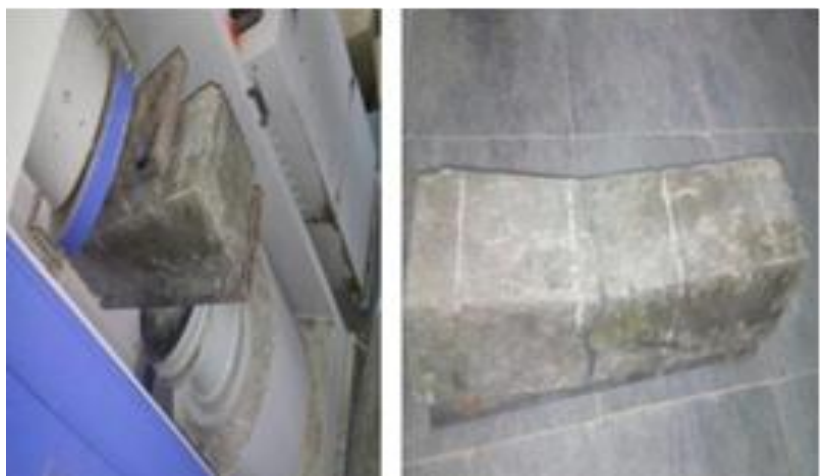

Figure 6: Testing of Beams in Flexural Testing Machine

\subsection{Durability Test}

The concrete acid resistance was observed by two types of tests named as Acid attack factor test and Acid durability factor test. The concentrations of acids in water are 5\% HCL and $5 \% \mathrm{H} 2 \mathrm{SO} 4$.concrete can be attacked by liquids with $\mathrm{pH}$ value less than 6.5 and attack is severe when $\mathrm{pH}$ value is below 5.5. At $\mathrm{pH}$ value below 4.5 , the attack is very severe. As the attack proceeds, all the cement compounds are broken down and leached away. Here HCL andH2SO4 which are having $\mathrm{pH}$ value 3.01 and 2.75 which cause a very severe attack are used to study the durability properties. To check acid resistance of concrete Hydro Chloric acid (HCL), Sulphuric Acid (H2SO4) is selected. The concentrations of acids in water are taken as 5\%. The standard specifications for this study are IS 516-1959 and ASTM C666-1997.
Preparation of $5 \% \mathrm{H} 2 \mathrm{SO} 4$ per Litres of Water:

The volume of acid to mix in water is calculated by the formula $\mathrm{C} 1 \mathrm{~V} 1=\mathrm{C} 2 \mathrm{~V} 2$

$\mathrm{C} 1$ is the Concentration of $\mathrm{H} 2 \mathrm{SO} 4=98 \% \mathrm{~V} 1$ is the Volume required $=20$ lit

$\mathrm{C} 2$ is the required concentration $=5 \% \mathrm{~V} 2$ is the required volume of acid Volume of $\mathrm{H} 2 \mathrm{SO} 4(\mathrm{~V} 2)=\mathrm{C} 2 \mathrm{~V} 2 / \mathrm{C} 1$

$=5 \times 20 / 98=1.02$ litres

i.e., to prepare 20 lit solutions of $\mathrm{H} 2 \mathrm{SO} 4$, volume of acid required is 1.02 litres

\section{Preparation of 5\% $\mathrm{HCl} 20$ per Litres of Water:}

The aicd volume to be in the water can be obtained from the formula

$\mathrm{C} 1 \mathrm{~V} 1=\mathrm{C} 2 \mathrm{~V} 2$

Where,

$\mathrm{C} 1$ is the Concentration of $\mathrm{HCl}=35 \%$

$\mathrm{V} 1$ is the Volume required $=20 \mathrm{lit}$

$\mathrm{C} 2$ is the required concentration $=5 \%$

$\mathrm{V} 2$ is the required volume of acid

Volume of $\mathrm{HCl}(\mathrm{V} 2)=\mathrm{C} 2 \mathrm{~V} 2 / \mathrm{C} 1$

$=5 \times 20 / 35$

$=2.85$ liters

i.e., to prepare 20 lit solutions of $\mathrm{HCl}$, volume of acid required is 2.85 liters
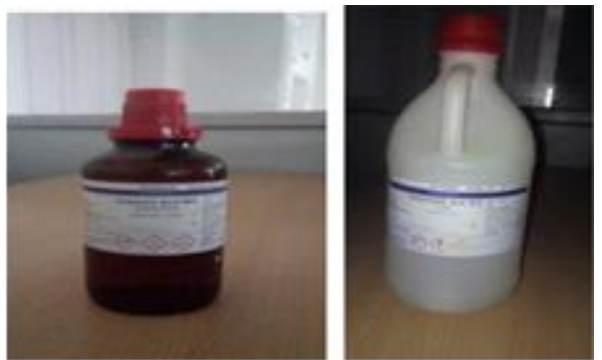

Figure 7: Sulphuric acid and $\mathrm{HCl}$

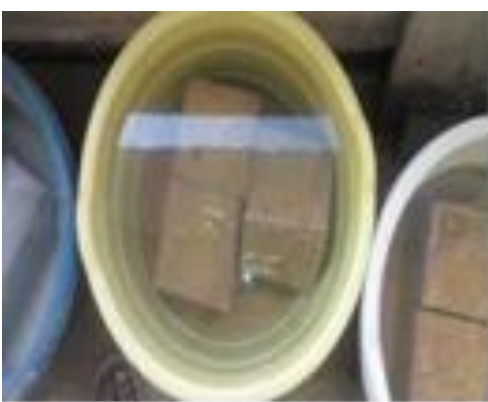

Figure 8: Acid curing

\section{Results}

The results for different mix proprtions are as follows:

Table 7: Results Using Sludge Ash in Concrete

\begin{tabular}{|c|c|c|c|c|c|c|}
\hline \multirow{2}{*}{$\%$} & \multicolumn{2}{|c|}{$\begin{array}{c}\text { Compressive } \\
\text { strength }\end{array}$} & \multicolumn{2}{c|}{$\begin{array}{c}\text { Split tensile } \\
\text { strength }\end{array}$} & \multicolumn{2}{c|}{$\begin{array}{c}\text { Flexural } \\
\text { strength }\end{array}$} \\
\cline { 2 - 7 } & 7 days & 28 days & 7 days & 28 days & 7 days & 28 days \\
\hline $0 \%$ & 19.38 & 34.5 & 2.12 & 2.34 & 4.01 & 4.21 \\
\hline $5 \%$ & 23.84 & 35.11 & 2.21 & 2.45 & 4.05 & 4.38 \\
\hline $\mathbf{1 0 \%}$ & $\mathbf{2 5 . 5 2}$ & $\mathbf{3 8 . 2 6}$ & $\mathbf{2 . 3 2}$ & $\mathbf{2 . 6 8}$ & $\mathbf{4 . 3 8}$ & $\mathbf{5 . 0 1}$ \\
\hline $15 \%$ & 24.54 & 36.89 & 2.24 & 2.54 & 4.12 & 4.62 \\
\hline
\end{tabular}


International Journal of Science and Research (IJSR)

ISSN (Online): 2319-7064

Index Copernicus Value (2015): 78.96 | Impact Factor (2015): 6.391

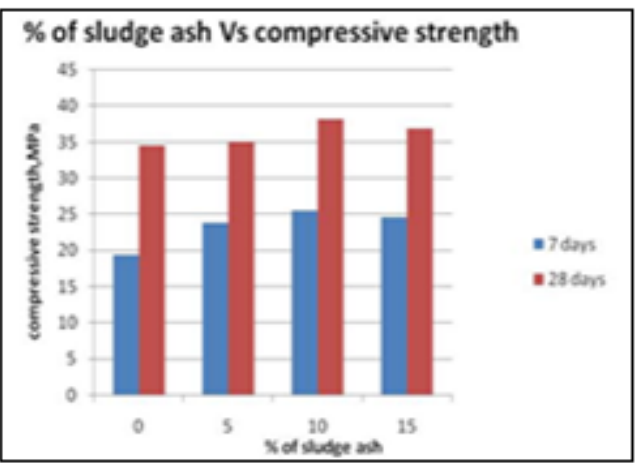

Graph 9: Graph for \% of sludge ash vs compressive strength [2]

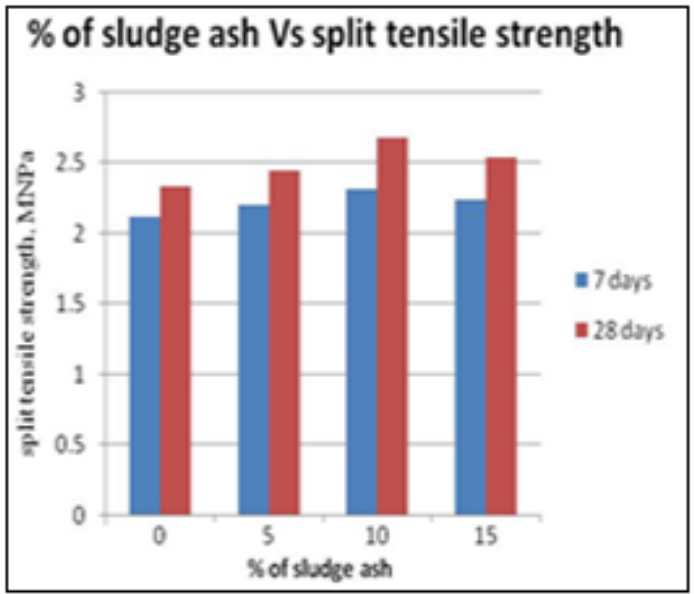

Graph 10: Graph for \% of sludge ash vs split tensile strength

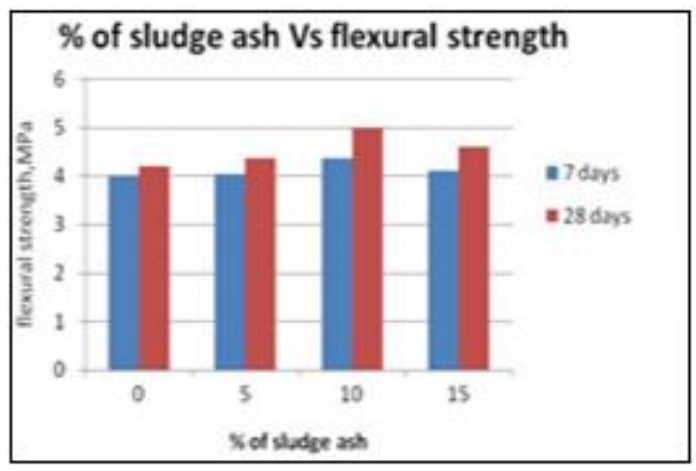

Graph 11: Graph for \% of sludge ash vs flexural strength

Table 8: Results by Adding Glass Fibres in Sludge Ash Concrete

\begin{tabular}{|c|c|c|c|c|c|c|}
\hline \multirow{2}{*}{$\%$} & \multicolumn{2}{|c|}{$\begin{array}{c}\text { Compressive } \\
\text { strength }\end{array}$} & \multicolumn{2}{c|}{$\begin{array}{c}\text { Split tensile } \\
\text { strength }\end{array}$} & \multicolumn{2}{c|}{$\begin{array}{c}\text { Flexural } \\
\text { strength }\end{array}$} \\
\cline { 2 - 7 } & 7 days & 28 days & 7 days & 28 days & 7 days & 28 days \\
\hline $0.1 \%$ & 26.12 & 38.88 & 2.31 & 2.66 & 4.18 & 4.99 \\
\hline $0.2 \%$ & 27.22 & 39.76 & 2.45 & 2.74 & 4.43 & 5.21 \\
\hline $\mathbf{0 . 3 \%}$ & $\mathbf{2 8 . 3 4}$ & $\mathbf{4 0 . 2 3}$ & $\mathbf{2 . 5 6}$ & $\mathbf{2 . 8 1}$ & $\mathbf{4 . 6}$ & $\mathbf{5 . 2 9}$ \\
\hline $0.4 \%$ & 26.81 & 38.11 & 2.43 & 2.67 & 4.51 & 5.06 \\
\hline
\end{tabular}

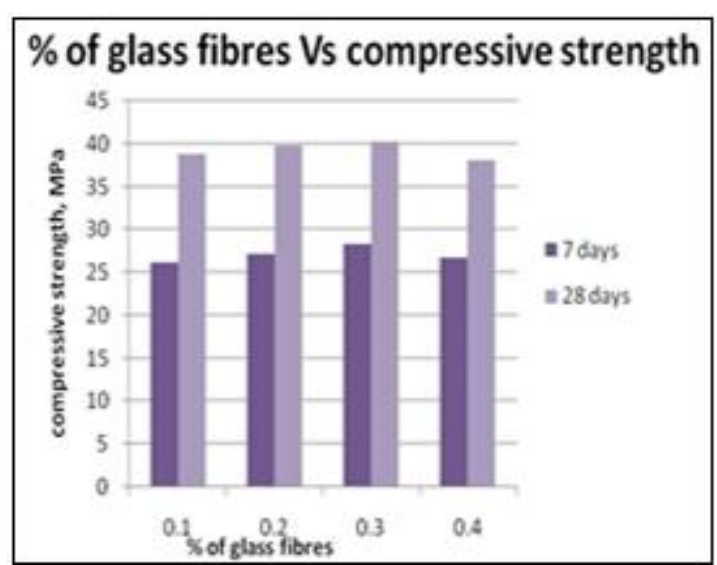

Graph 12: Graph for \% of glass fibres vs compressive strength

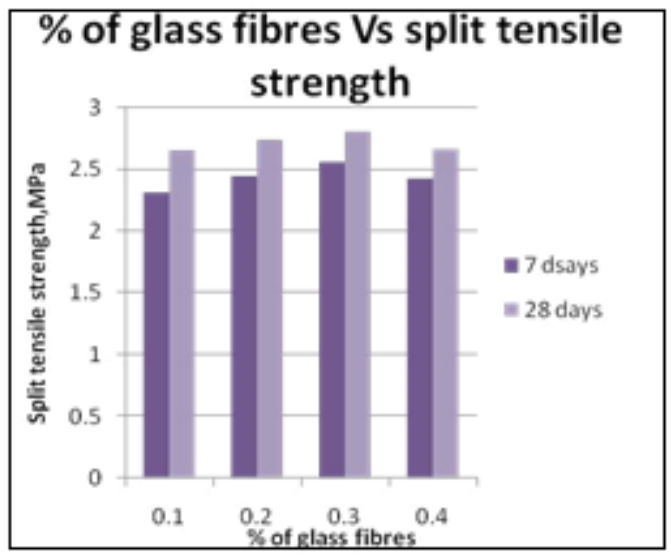

Graph 13: Graph for \% of glass fibres vs split tensile strength

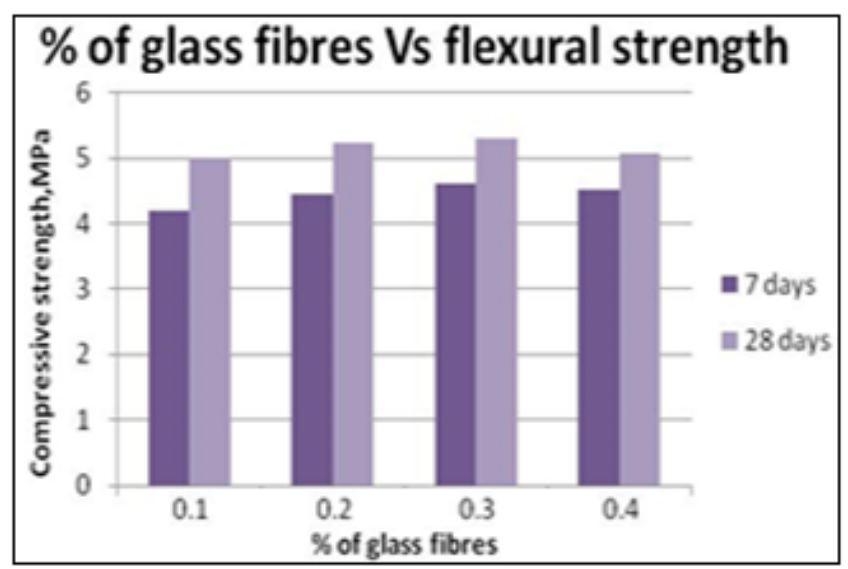

Graph 14: Graph for \% of glass fibres vs flexural strength

Table 9: Results by Adding Steel Fibres in Sludge Ash Concrete

\begin{tabular}{|c|c|c|c|c|c|c|}
\hline \multirow{2}{*}{$\%$} & \multicolumn{2}{|c|}{$\begin{array}{c}\text { Compressive } \\
\text { strength }\end{array}$} & \multicolumn{2}{c|}{$\begin{array}{c}\text { Split tensile } \\
\text { strength }\end{array}$} & \multicolumn{2}{c|}{$\begin{array}{c}\text { Flexural } \\
\text { strength }\end{array}$} \\
\cline { 2 - 7 } & 7 days & 28 days & 7 days & 28 days & 7 days & 28 days \\
\hline $0.5 \%$ & 26.67 & 38.41 & 2.38 & 2.71 & 4.41 & 5.18 \\
\hline $\mathbf{1 \%}$ & $\mathbf{2 8 . 8 1}$ & $\mathbf{4 0 . 4 1}$ & $\mathbf{2 . 5 6}$ & $\mathbf{2 . 9 8}$ & $\mathbf{4 . 6 2}$ & $\mathbf{5 . 3 1}$ \\
\hline $1.5 \%$ & 27.16 & 38.12 & 2.41 & 2.82 & 4.51 & 5.26 \\
\hline $2 \%$ & 26.81 & 37.41 & 2.32 & 2.76 & 4.37 & 5.21 \\
\hline
\end{tabular}


International Journal of Science and Research (IJSR)

ISSN (Online): 2319-7064

Index Copernicus Value (2015): 78.96 | Impact Factor (2015): 6.391

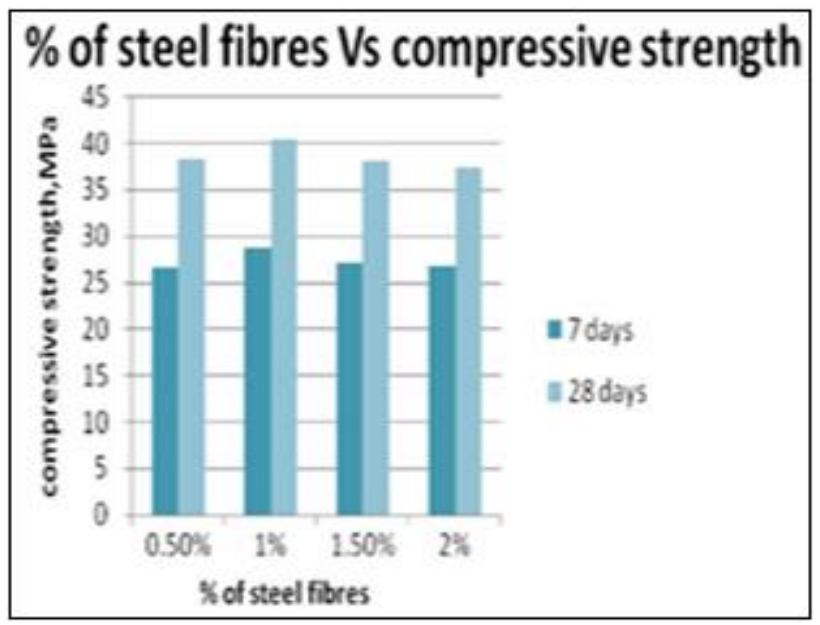

Graph 15: Graph for \% of steel fibres vs compressive strength

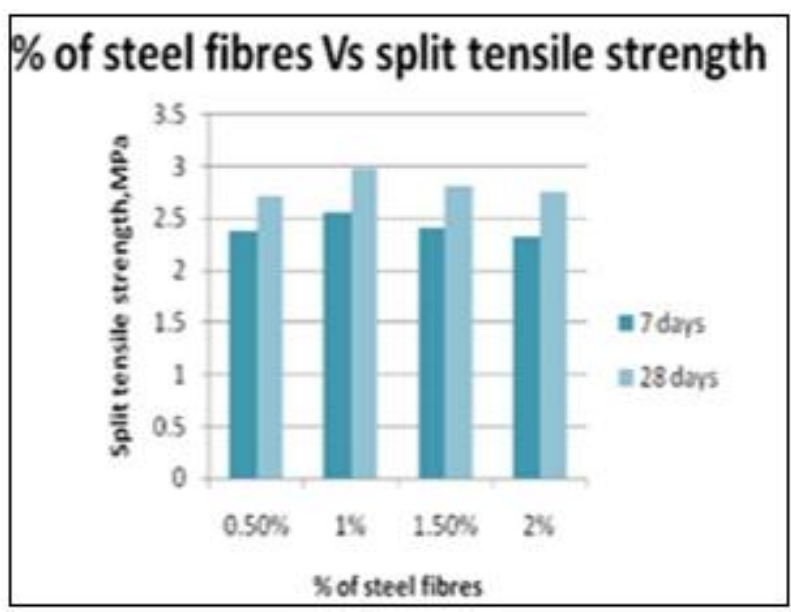

Graph 16: Graph for \% of steel fibres vs split tensile strength

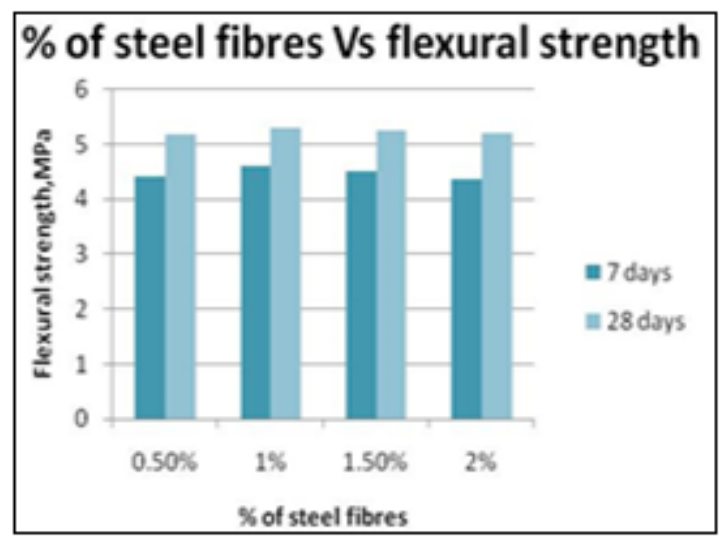

Graph 17: Graph for \% of Steel Fibres Vs Flexural Strength

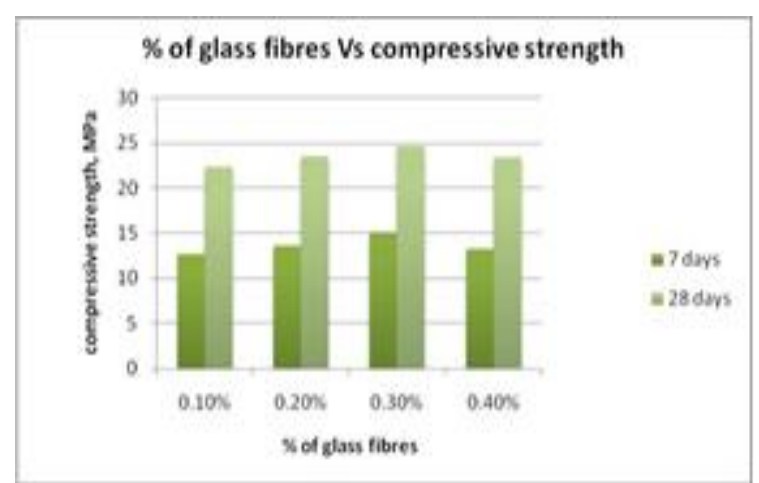

Graph 18: Graph for \% of glass fibres vs compressive strength

Table 11: Durability Results by Adding Glass Fibres in Sludge Ash Concrete

\begin{tabular}{|c|c|c|c|}
\hline $\begin{array}{c}\text { Glass } \\
\text { fibers }\end{array}$ & $\begin{array}{c}\text { Curing under } \\
0.5 \% \mathrm{HCl} \% \\
\text { weight loss } \\
\text { after 28 days }\end{array}$ & $\begin{array}{c}\text { Compressive } \\
\text { strength }\left(\mathrm{N} / \mathrm{mm}^{2}\right) \\
7 \text { days }(5 \% \mathrm{HCl})\end{array}$ & $\begin{array}{c}\text { Compressive } \\
\text { strength }\left(\mathrm{N} / \mathrm{mm}^{2}\right) \\
28 \text { days }(5 \% \mathrm{HCl})\end{array}$ \\
\hline $0.5 \%$ & 2.3 & 16.12 & 28.88 \\
\hline $1 \%$ & 2.46 & 17.22 & 29.76 \\
\hline $1.5 \%$ & 2.66 & 18.44 & 30.23 \\
\hline $2 \%$ & 2.69 & 16.81 & 28.11 \\
\hline
\end{tabular}

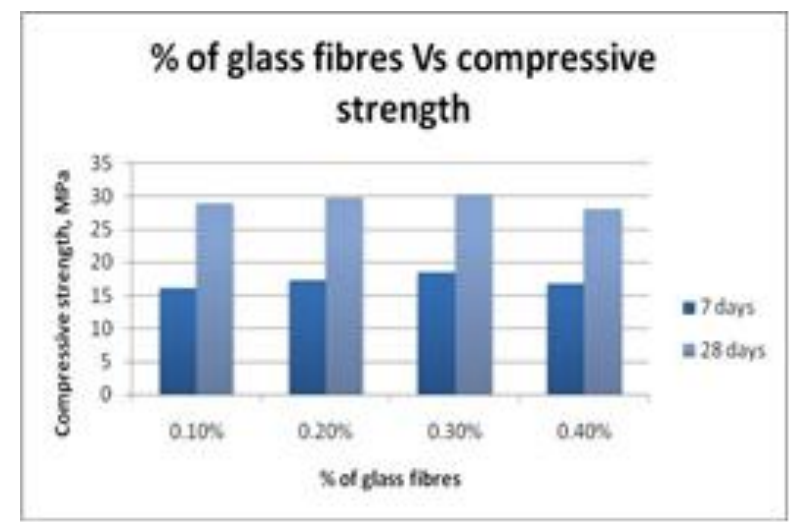

Graph 19: Graph for \% of glass fibres vs compressive strength

Table 12: Durability Results by Adding Steel Fibres in Sludge Ash Concrete

\begin{tabular}{|c|c|c|c|}
\hline $\begin{array}{l}\text { Steel } \\
\text { fibers }\end{array}$ & $\begin{array}{c}\text { Curing under } \\
0.5 \% \mathrm{H}_{2} \mathrm{So}_{4} \% \\
\text { weight loss } \\
\text { after } 28 \text { days }\end{array}$ & $\begin{array}{c}\text { Compressive } \\
\text { strength }\left(\mathrm{N} / \mathrm{mm}^{2}\right) \\
7 \text { days }\left(5 \% \mathrm{H}_{2} \mathrm{So}_{4}\right)\end{array}$ & $\begin{array}{c}\text { Compressive } \\
\text { strength }\left(\mathrm{N} / \mathrm{mm}^{2}\right) \\
28 \text { days }\left(5 \% \mathrm{H}_{2} \mathrm{So}_{4}\right)\end{array}$ \\
\hline $0.5 \%$ & 4.46 & 14.44 & 23.04 \\
\hline $1 \%$ & 5.66 & 15.85 & 24.81 \\
\hline $1.5 \%$ & 6.41 & 15.5 & 24.54 \\
\hline $2 \%$ & 7.11 & 14.21 & 24.11 \\
\hline
\end{tabular}

Table10: Durability Results by Adding Glass Fibres in Sludge Ash Concrete

\begin{tabular}{|c|c|c|c|}
\hline $\begin{array}{c}\text { Glass } \\
\text { fibers }\end{array}$ & $\begin{array}{c}\text { Curing under } \\
0.5 \% \mathrm{H}_{2} \mathrm{So}_{4} \% \\
\text { weight loss } \\
\text { after 28 days }\end{array}$ & $\begin{array}{c}\text { Compressive } \\
\text { strength }\left(\mathrm{N} / \mathrm{mm}^{2}\right) \\
7 \text { days }\left(5 \% \mathrm{H}_{2} \mathrm{So}_{4}\right)\end{array}$ & $\begin{array}{c}\text { Compressive } \\
\text { strength }\left(\mathrm{N} / \mathrm{mm}^{2}\right) \\
28 \text { days }\left(5 \% \mathrm{H}_{2} \mathrm{So}_{4}\right)\end{array}$ \\
\hline $0.1 \%$ & 4.16 & 12.66 & 22.35 \\
\hline $0.2 \%$ & 5.59 & 13.58 & 23.44 \\
\hline $0.3 \%$ & 6.34 & 14.99 & 24.68 \\
\hline $0.4 \%$ & 6.35 & 13.24 & 23.33 \\
\hline
\end{tabular}




\section{International Journal of Science and Research (IJSR) ISSN (Online): 2319-7064}

Index Copernicus Value (2015): 78.96 | Impact Factor (2015): 6.391

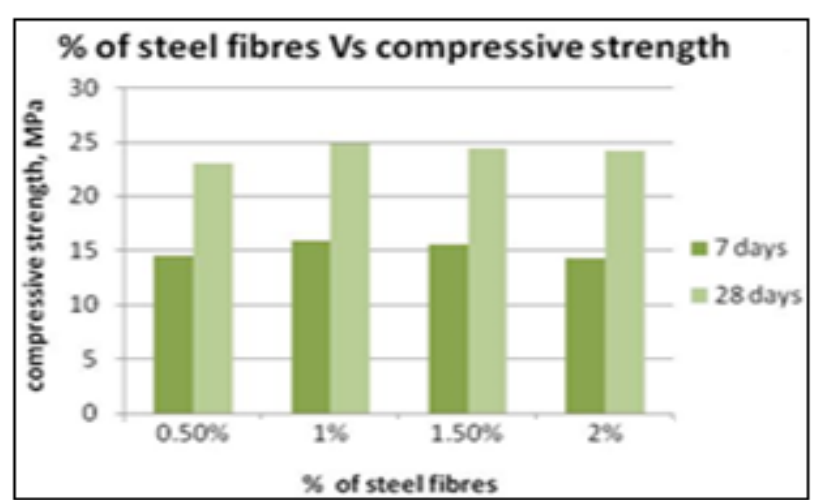

Graph 20: Graph for \% of steel fibres vs compressive strength

Table 13: Durability Results by Adding Steel Fibres in Sludge Ash Concrete

\begin{tabular}{|c|c|c|c|}
\hline $\begin{array}{l}\text { Steel } \\
\text { fibers }\end{array}$ & $\begin{array}{c}\text { Curing under } \\
0.5 \% \mathrm{HCl} \% \\
\text { weight loss after } \\
28 \text { days }\end{array}$ & $\begin{array}{c}\text { Compressive } \\
\text { strength }\left(\mathrm{N} / \mathrm{mm}^{2}\right) \\
\text { 7days }(5 \% \mathrm{HCl})\end{array}$ & $\begin{array}{c}\text { Compressive } \\
\text { strength }\left(\mathrm{N} / \mathrm{mm}^{2}\right) \\
\text { 28days }(5 \% \mathrm{HCl})\end{array}$ \\
\hline $0.5 \%$ & 2.33 & 16.67 & 28.41 \\
\hline $1 \%$ & 2.41 & 18.81 & 30.41 \\
\hline $1.5 \%$ & 2.58 & 17.16 & 28.12 \\
\hline $2 \%$ & 2.63 & 16.81 & 27.41 \\
\hline
\end{tabular}

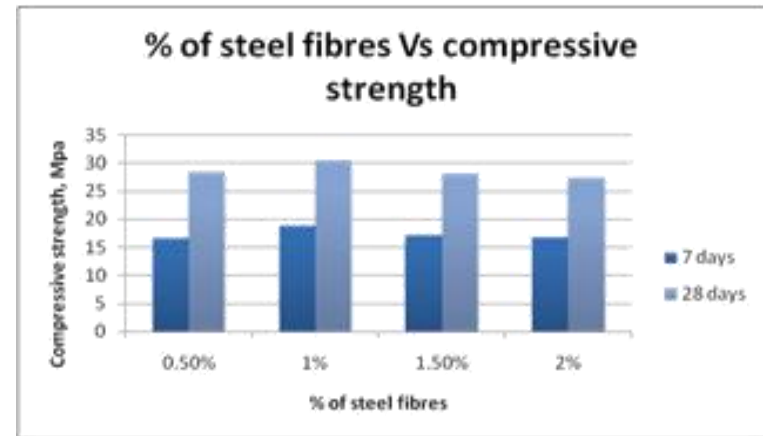

Graph 21: Graph for \% of steel fibres vs compressive strength

\section{Conclusions}

- By replacing waste paper sludge ash to the concrete, the optimum is obtained at $10 \%$ and compressive strength obtained is $38.26 \mathrm{MPa}$ and increase in strength is $9.827 \%$ than conventional concrete.

- By replacing waste paper sludge ash to the concrete, the optimum is obtained at $10 \%$ and split tensile strength obtained is $2.68 \mathrm{MPa}$ and increase in strength is $12.688 \%$ than conventional concrete.

- By replacing waste paper sludge ash to the concrete, the optimum is obtained at $10 \%$ and flexural strength obtained is $5.01 \mathrm{MPa}$ and

- Increase in strength is $15.96 \%$ than conventional concrete.

- By adding glass fibres, the optimum is obtained at $0.3 \%$ and the value obtained is $40.23 \mathrm{MPa}$ for compressive strength and increase in strength is $14.24 \%$ than conventional concrete..

- By adding glass fibres, the optimum is obtained at $0.3 \%$ and the value obtained is $2.81 \mathrm{MPa}$ for split tensile strength and increase in strength is $16.72 \%$ than conventional concrete.
- By adding glass fibres, the optimum is obtained at $0.3 \%$ and the value obtained is $5.29 \mathrm{MPa}$ for flexural strength and increase in strength is $19.19 \%$ than conventional concrete.

- By adding steel fibres, the optimum is obtained at $1 \%$ and the value obtained is $40.41 \mathrm{MPa}$ for split tensile strength and increase in strength is $14.62 \%$ than conventional concrete.

- By adding steel fibres, the optimum is obtained at $1 \%$ and the value obtained is $2.98 \mathrm{MPa}$ for split tensile strength and increase in strength is $21.47 \%$ than conventional concrete..

- By adding steel fibres, the optimum is obtained at $1 \%$ and the value obtained is $5.31 \mathrm{MPa}$ for flexural strength and increase in strength is $20.71 \%$ than conventional concrete.

- In durability the weight loss is higher in $\mathrm{H} 2 \mathrm{SO} 4$ than $\mathrm{HCl}$.

- Glass fibres shown better results than steel fibres in durability results

\section{References}

[1] Sajad Ahmad, M.Iqbal Malik, Muzaffar Bashir Wani andRafiq Ahmad, "Study on concrete involving use of Waste paper sludge ash as partial replacement of cement", IOSRJEN, Vol.3, Issue 11, Nov.2013.

[2] Prof. Jayeshkumar Pitroda, Dr. L.B.Zala and Dr.F.S.Umrigar, "Innovative use of paper industry waste (hypo sludge) in design mix concrete", IJAET, Vol.4, Issue1, Mar.2013.

[3] Abdullah shahbaz khan, Ram panth, Gagan Krishna P.R. and Suresh G.Patil, "Structural performance of concrete by partial replacement of cement with hypo sludge (paper waste)",IJETE, Vol. 1, Issue 7,Aug 2014.

[4] Avinash Gornale, S Ibrahim Quadri, Mehmoodquadri, Syed Md Akramali and Syed Sham Suddin Hussaini "Strength Aspects of Glass Fiber Reinforced Concrete", IJSER, Volume 3, Issue, (July 2012).

[5] D.Neeraja, "Experimental Investigations on Strength Characteristics of Steel Fiber Reinforced Concrete", IJSER Volume 2, Issue 07, (February 2013).

[6] A.Sumathi and K. Saravana Raja Mohan "Study on theStrength and Durability Characteristics of High Strength Concrete with Steel Fibers" IJCR.volume.08 (2015).

[7] Milind and V. Mohod, "Performance of Steel Fiber Reinforced Concrete", Volume.1,Issue 12(December 2012).

[8] A.M.Shende, A.M. Pande and M. Gulfampathan "Experimental study on steel fiber reinforced concrete for M-40 grade", IRJES 4, issue2,(February2013volume).

[9] Mamta B. Rajgor and Jayeshkumar Pitroda, "A Study on Paper Industry Waste: Opportunity for Development of Low Cost Concrete in Indian Contest", pp. 90-92, 2013.

[10] IS 7320:1974 "Specification for concrete slump test apparatus." 